\title{
Seasonal population fluctuations and damage rates of Capnodis tenebrionis $L$. and Capnodis carbonaria L. (Coleoptera: Buprestidae) in apricot orchards in Malatya province
}

Malatya ili kayısı bahçelerinde Capnodis tenebrionis L. ve Capnodis carbonaria L. (Coleoptera: Buprestidae) türlerinin mevsimsel popülasyon yoğunluğu ve zarar oranları

\section{Zeynep KARACA ${ }^{1 \mathscr{O}}$ (D), Nihat DEMiREL ${ }^{1}$}

${ }^{1}$ Hatay Mustafa Kemal University, Faculty of Agriculture, Department of Plant Protection, Antakya-Hatay, Turkey.

MAKALE BILGISI / ARTICLE INFO

Makale tarihçesi / Article history:

DOI: $10.37908 / \mathrm{mkutbd} .956163$

Geliş tarihi /Received:22.06.2021

Kabul tarihi/Accepted:27.08.2021

\section{Keywords:}

Capnodis tenebrionis, Capnodis carbonaria, apricot, population density, damage rate, Malatya province.

Corresponding author: Nihat DEMIREL

$\bowtie: \underline{\text { ndemirel@mku.edu.tr }}$
ÖZET / A B STR ACT

Aims: Seasonal population fluctuations and damage rates of Capnodis tenebrionis L. and Capnodis carbonaria L. (Coleoptera: Buprestidae) in apricot orchards in Malatya province.

Methods and Results: The study was conducted in 2010-2011 in thirteen apricot orchards in Akçadağ, Battalgazi and Doğanşehir districts of Malatya province. The study was carried out in seven and six apricot orchards in 2010 and 2011 respectively. In both years, the sampled apricot orchards were visited every week and counts were done by visual inspection method. After two years of the study, the population density of pest varied between each sampling year. A total of 1020 Capnodis adults were collected in 2010 from all the sampling areas. Among these, 805 were $C$. tenebrionis $\left(6880^{\circ}: 117 \%\right)$ and 215 were $C$. carbonaria $\left(193 \sigma^{r}: 22 \%\right)$. The first adult male and female emergence for $C$. tenebrionis was observed on $27^{\text {th }}$ April and $18^{\text {th }}$ May in 2010 respectively. For $C$. carbonaria first male and female emergence was observed on $22^{\text {nd }}$ June and $20^{\text {th }}$ July respectively. A total of 1170 Capnodis adults were collected in 2011 from all the sampling areas. Among these, 903 were $C$. tenebrionis (7900 $: 113 \%)$ and 267 were C. carbonaria $\left(225 \sigma^{\top}: 42 \%\right)$. The first adult male and female emergence for $C$. tenebrionis was observed on $23^{\text {rd }}$ April and $30^{\text {th }}$ April in 2011 respectively.

Conclusions: In 2010, the largest percentages of $C$. tenebrionis male were collected in August, July and September, while those of its female were collected in August, September and July. The highest number of $C$. carbonaria male and female were collected in August, September and July. In 2011, the largest percentages of $C$. tenebrionis male and female were collected in July, August, September and June. The largest percentages of $C$. carbonaria male were collected in July, August, September and June, while those of its female were collected in July, August and June.

Significance and Impact of the Study: The higher number of $C$. tenebrionis was collected by visual inspection method. The higher number of $C$. tenebrionis was collected than $C$. carbonaria in both years. The damage rates were observed on various varieties between 0.7-30\% in 2010 and $1.3-30 \%$ in 2011.

\footnotetext{
Atıf / Citation: Karaca Z, Demirel N (2021) Seasonal population fluctuations and damage rates of Capnodis tenebrionis L. and Capnodis carbonaria L. (Coleoptera: Buprestidae) in apricot orchards in Malatya province. MKU. Tar. Bil. Derg. 26(3) : 661-669. DOI: 10.37908/mkutbd.956163
} 


\section{INTRODUCTION}

Apricot, Prunus armeniaca L. (Rosales: Rosaceae), is one of the most important stone fruits and a total produce of 4,257,241 tons of fruit per annum in the world, about 985,000 tons of this amount is produced by Turkey (FAO, 2018). Apricot is grown in almost all orchards in Malatya, where is the most important apricot production region in Turkey (Asma, 2000; Ercişli, 2009). Malatya province has 8 million apricot trees, $73 \%$ of which consists of 'Hacıhaliloğlu', a cultivar perfectly suitable for drying, followed by 'Kabaaşı' (17\%); other cultivars include 'Hasanbey', 'Çataloğlu', 'Soğanci', 'Çöloğlu', 'Alyanak', 'Sekerpare', 'Kurukabuk' and 'Ismailaga' (Asma, 2000; Asma and Birhanlı, 2004). The peach flatheaded rootborer, Capnodis tenebrionis L. and the almond flatheaded rootborer, Capnodis carbonaria Klug have been known as important pests of Rosaceae, particularly apricot (Prunus armeniaca L.), plum ( $P$. domestica L.), almond ( $P$. amygdalus Batsch), cherry ( $P$. vulgaris $L$.), nectarine and peach $(P$. persica L.) (Beu-Yebuda et al.1997; Lodos and Tezcan, 1995; Tezcan, 1995; Ak and Çam, 1998; Martin et al., 1998; Tozlu and Özbek, 2000; Kanat and Tozlu, 2001; Mendel et al., 2003; Çınar et al. 2004; Vit, 2004; Bonsignore and Bellamy, 2007; Bonsignore et al., 2007; Gindin et al., 2009; Ertop and Özpınar, 2011; Dicenta et al., 2011; Karaca and Demirel, 2011; Karaca, 2012; Zobar and KIvan, 2019; Zobar et al., 2019).

Adults of Capnodis feed on the cortex of twigs and young branches and leaf petioles (Rivnay, 1946) and usually prefer weakened and diseased trees rather than vigorous ones prior to mating and oviposition (Malagon, 1989; Ben-Yehuda et al.,2000; Mendel et al.,2003; García del Pino and Morton, 2005; Bonsignore and Bellamy, 2007; Karaca, 2012). Female may lay more than 1000 eggs (Rivnay, 1944) and oviposit on the ground, usually into cracks of dry soil or under stones (Rivnay, 1944; Rivnay, 1946). The neonate larvae feed on the cortex of roots (Rivnay, 1944; Rivnay, 1945; Lodos and Tezcan, 1995; Mendel et al., 2003; Karaca, 2012). The major damage is caused by the larvae in the roots tunnelling between the wood and the bark (Rivnay, 1944; Rivnay, 1946; Lodos and Tezcan, 1995; Ben-Yehuda et al., 2000; Mendel et al., 2003; Bonsignore et al., 2007; Gindin et al., 2009; Dicenta et al., 2011; Karaca, 2012). One-year-old seedlings are killed by single larvae; a few larvae can lead to the death of an adult tree within one or two years (BenYehuda et al., 2000; Mendel et al., 2003; García del Pino and Morton, 2005; Bonsignore and Bellamy, 2007; Karaca, 2012). The current study was to determine seasonal population fluctuations and damage rates of $C$. tenebrionis and C. carbonaria (Coleoptera: Buprestidae) in apricot orchards in Malatya province.

\section{MATERIALS and METHODS}

The study was conducted in 2010-2011 at thirteen apricot orchards in Akçadağ, Battalgazi and Doğanşehir districts of Malatya province in Turkey. In the first year, the study was carried out in seven apricot orchards, two of which were located in Akçadağ (orchard I (Kabaaşı), orchard II (Kabaaşı + Hacıhaliloğlu), three of them in Battalgazi (orchard I (Hacıhaliloğlu + Hasanbey), orchard II (Hacıhaliloğlu + Hasanbey), orchard III (Hacıhaliloğlu + Hasanbey), and two of them in Doğanşehir (orchard I (Kabaaşı), orchard II (Hacıhaliloğlu + Kabaaşı + Hasanbey + Çataloğlu ) districts (Table 1). In the second year, the study was conducted in six apricot orchards, two of which were located in Akçadağ (orchard I (Kabaaşı), orchard II (Kabaaşı + Hacıhaliloğlu), three of them in Battalgazi (orchard I (Hacıhaliloğlu + Hasanbey), orchard II (Hacıhaliloğlu + Hasanbey), orchard III (Hacıhaliloğlu + Hasanbey), and one of them in Doğanşehir (orchard II (Hacıhaliloğlu + Kabaaşı + Hasanbey + Çataloğlu ) districts.

The sampled apricot orchards contain 'Kabaaşı', 'Hacıhaliloğlu', 'Hasanbey' and 'Çataloğlu' varieties. The sampling was carried out from 27 April to 5 October in 2010 and from 23 April to 22 October in 2011. In both years, the sampled apricot orchards were visited every week in early morning and adults of flat-headed borers were collected by visual inspection method on the trunk and root part of apricot trees in each of sampled apricot orchards. The collected Capnodis spp from each orchard were put into petri dishes and brought to the laboratory. They were sorted out according to the species and gender and their numbers of each species were recorded. The Capnodis species collected from each apricot orchard were selected and separated by using the Capnodis identification keys prepared by Tezcan (1990) and Tozlu and Özbek (2000). All data were analyzed by analysis of variance (ANOVA) with using the SAS software (SAS Institute Inc., 1998).

Damage Rates in 2010-2011. In the preliminary study conducted in various apricot orchards in Malatya province, the Capnodis larvae, varying between 20-95 in different stages, were found in the root part of examined dried or peaky apricot trees removed from the orchard. Therefore, the based on the preliminary study mentioned above, the percentage of Capnodis 
damage was calculated by counting all dried or peaky apricot trees in each of the sampled apricot orchards and multiplying by a hundred and then dividing by the total number of trees in each of the apricot orchards in order to calculate the percentage of the damaged trees within the particular orchard.

Table 1. Districts and village of sampled apricot orchards, their varieties and total area in 2010-2011.

\begin{tabular}{lllc}
\hline Districts/village & Sampled orchards & Varieties of apricot & Total area (decare) \\
\hline Akçadağ/Bahri & Orchard I & Kabaaşı & 3 \\
Akçadağ/Bahri & Orchard II & Kabaaşı + Hacıhaliloğlu & 12 \\
Battalgazi/Merkez & Orchard I & Hacıhaliloğlu+Hasanbey & 15 \\
Battalgazi/Merkez & Orchard II & Hacıhaliloğlu+Hasanbey & 6 \\
Battalgazi/Merkez & Orchard III & Hacıhaliloğlu+Hasanbey & 7 \\
Doğanşehir/Sürgü & Orchard I & Kabaaşı & 5 \\
Doğanşehir/Cumhuriyet & Orchard II & Hacıhaliloğlu + Kabaaşı + & 125 \\
Örnek Köy & & Hasanbey+Çataloğlu & \\
\hline
\end{tabular}

\section{RESULTS and DISCUSSION}

Seasonal population fluctuations of $C$. tenebrionis and C. carbonaria were different in each of sampling year. Both pest species were found in all sampled apricot orchards in 2010-2011. In the first year, seven apricot orchards were sampled in Akçadağ, Battalgazi and
Doğanşehir districts. A total of 1020 Capnodis adults were collected by visual inspection method at seven sampled apricot orchards. A total of $805 \mathrm{C}$. tenebrionis $\left(6880^{r}: 117 \%\right)$ adults were collected by visual inspection method from all the sampling areas (Figure 1).

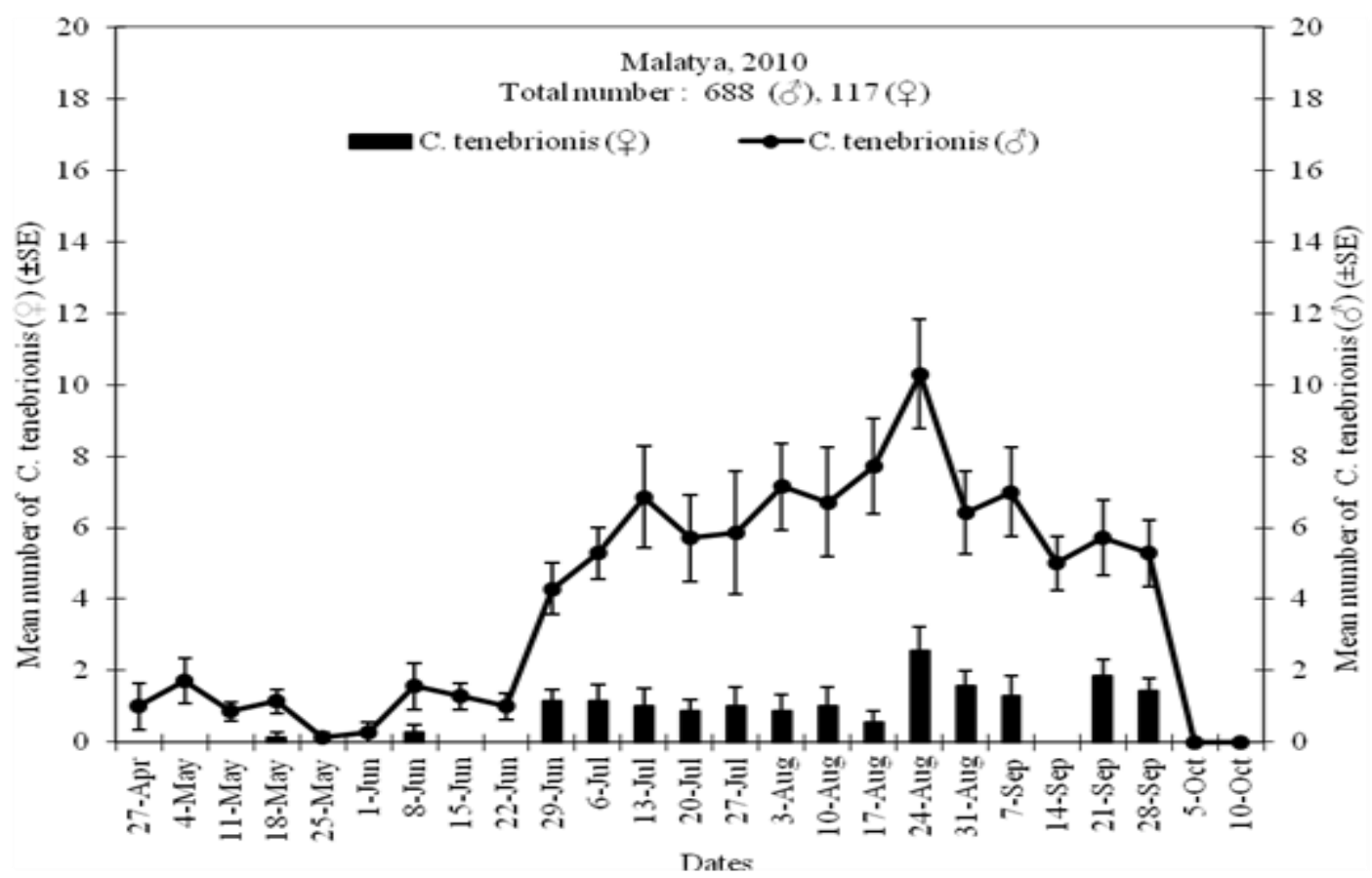

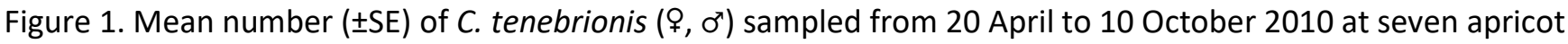
orchards in Malatya province.

The population fluctuation of male $\left(\sigma^{\top}\right)$ and female ( $(\$)$ adults varied during the sampling period. The first adult male emergence for $C$. tenebrionis was observed on $27^{\text {th }}$ April and the first female emergence was observed 
on $18^{\text {th }}$ May in 2010. The highest mean number of the collected male $\left(\sigma^{\prime}\right)$ were recorded on 24 August, followed by 3, 17 August, 7 September and 10 August. In addition, the highest mean number of the collected female (\$) were recorded on 24 August, followed by 21 September, 31 August and 28 September. The highest number of male adults was observed in August, July and September. Moreover, The highest number of female adults was observed in August, September and July. Zobar and Kivan (2019) reported that the highest population density of Capnodis tenebrionis was observed in July on various cherry rootstocks.

A total of 215 C. carbonaria (1930':22\%) adults were collected by visual inspection method from all the sampling areas (Figure 2).

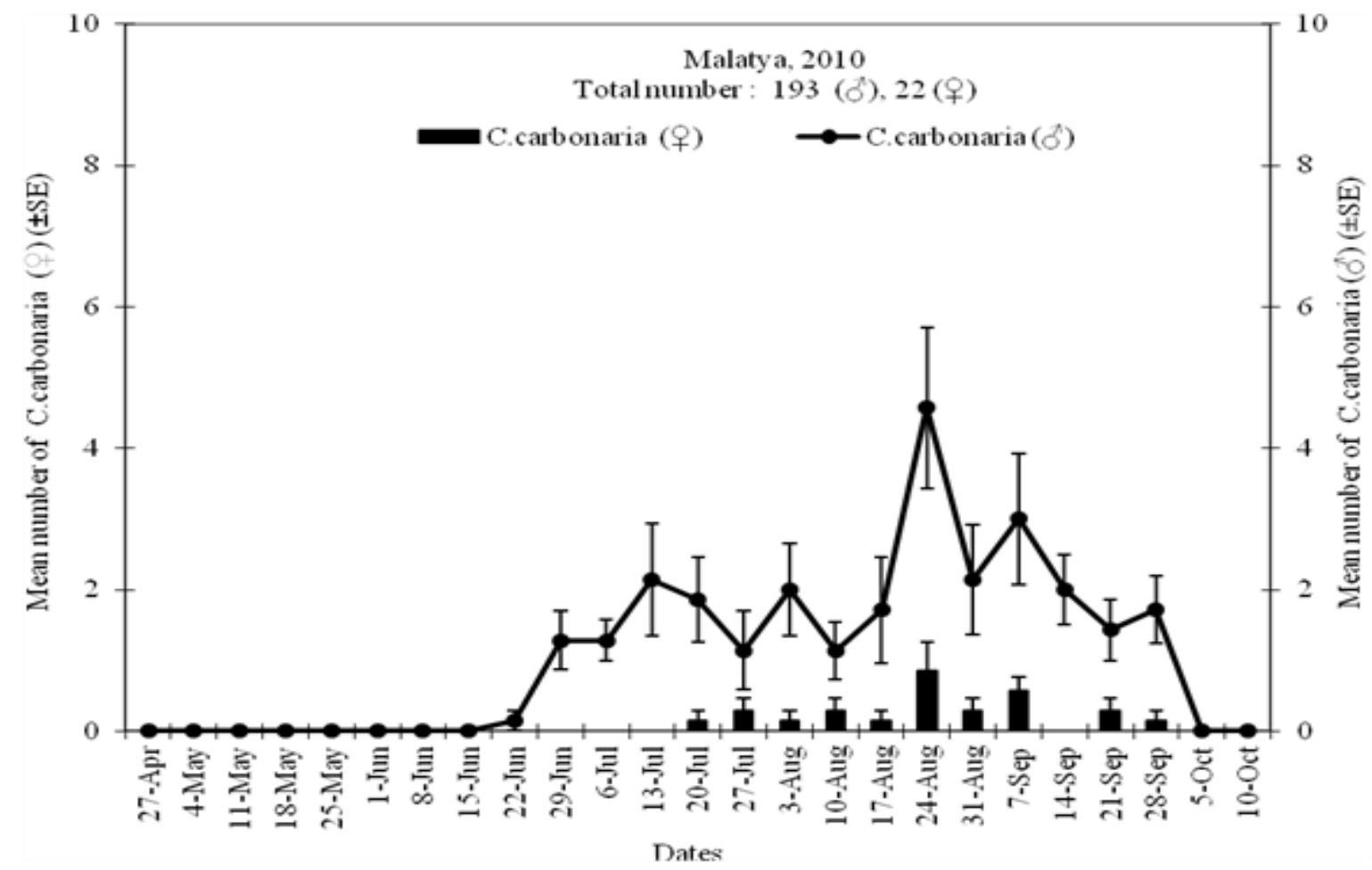

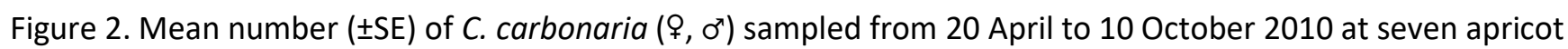
orchards in Malatya province.

The population fluctuation of male $\left(\sigma^{\top}\right)$ and female ( $(\$)$ adults varied during the sampling period. The first adult male emergence for $C$. carbonaria was observed on $22^{\text {nd }}$ June and the first female emergence was observed on $20^{\text {th }}$ July in 2010 . The highest mean number of the collected male $\left(\sigma^{\prime}\right)$ were recorded on 24 August, followed by 7 September, 13 July, 31 July, 2 August and 14 September. In addition, the highest mean number of the collected female ( $($ ) were recorded on 24 August, followed by 7 September and 31 August. The highest number of male and female adults was in August, September and July. In the second year, six apricot orchards were sampled in Akçadağ, Battalgazi and Doğanşehir districts. A total of 1170 Capnodis adults were collected by visual inspection method at six sampled apricot orchards, while a total of $903 \mathrm{C}$. tenebrionis $\left(7900^{1}: 113 \%\right)$ adults were collected (Figure
$3)$. The population fluctuation of male $\left(\sigma^{\top}\right)$ and female (P) adults varied during the sampling period. The first adult male emergence for $C$. tenebrionis was observed on $23^{\text {rd }}$ April and the first female emergence was observed on 30th April in 2011. The highest mean number of the collected male $\left(\sigma^{7}\right)$ were recorded on 21 August, followed by 4 September, 7,14 August and 10 July. In addition, the highest mean number of the collected female (\$) were recorded on 28 August, followed by 10, 17 July, 14 August and 4 September. The highest number of male and female adults was in July, August, September and June. Zobar and Kivan (2019) reported that the highest population density of C. tenebrionis was observed in July on various cherry rootstocks. 


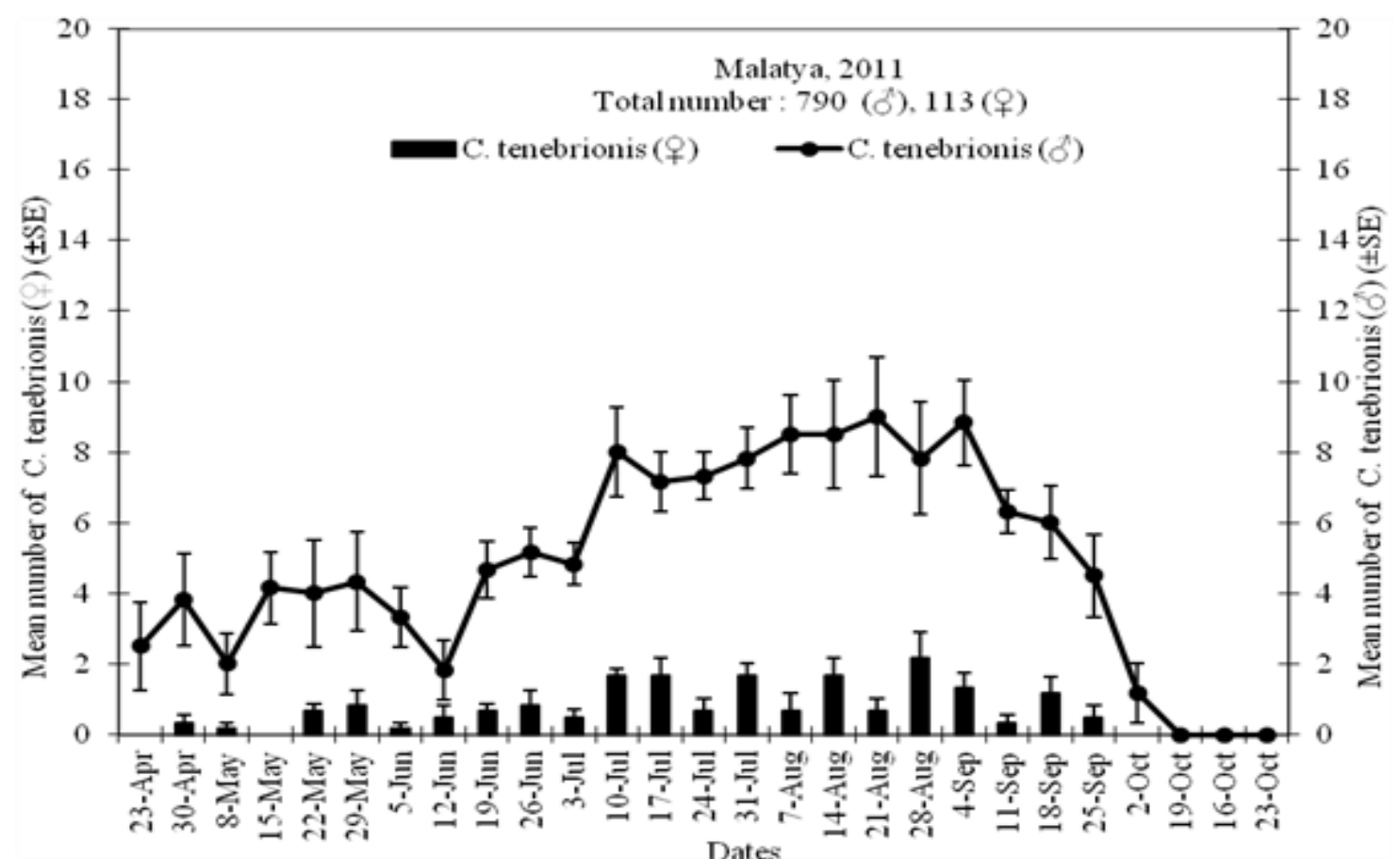

Figure 3. Mean number $( \pm \mathrm{SE})$ of $C$. tenebrionis $\left(\$, \sigma^{\top}\right)$ sampled from 17 April to 23 October 2011 at six apricot orchards in Malatya province.

A total of 267 C. carbonaria (2250 $42 \%$ ) adults were collected by visual inspection method from all the sampling areas (Figure 4). The population fluctuation of male $\left(\sigma^{7}\right)$ and female (\$) adults varied during the sampling period. The first adult male and female emergence for $C$. carbonaria was observed on $30^{\text {th }}$ April in 2011. The highest mean number of the collected male

$\left(0^{\prime}\right)$ were recorded on 31 July, followed by 21,28 August. In addition, the highest mean number of the collected female ( $\%$ ) were recorded on 31 July. The largest percentages of male adults was in July, August, September and June. In addition, the highest number of female adults was observed in July, August and June.

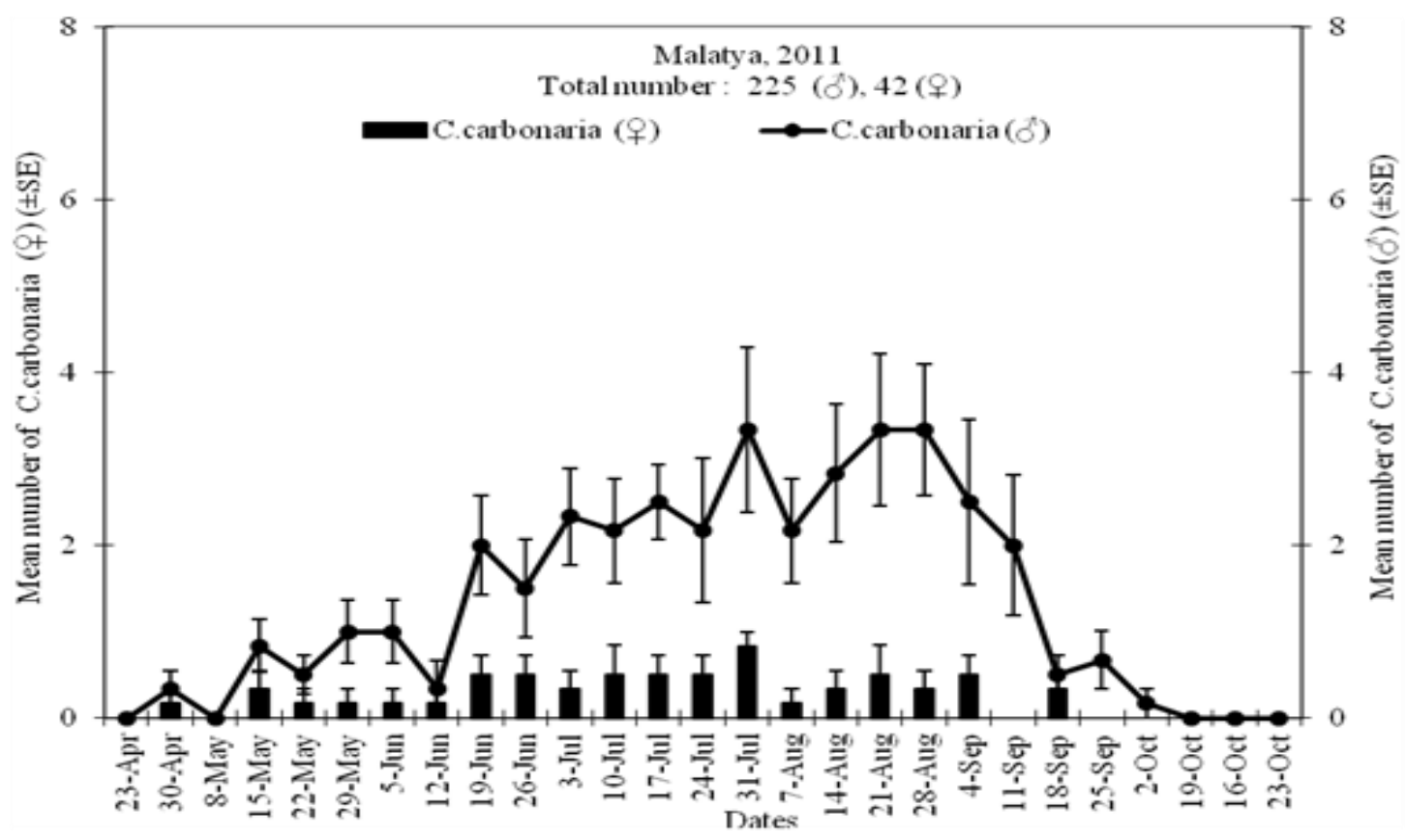

Figure 4. Mean number $( \pm \mathrm{SE})$ of $C$. carbonaria $\left(\$, \mathrm{o}^{\top}\right)$ sampled from 17 April to 23 October 2011 at six apricot orchards in Malatya province. 
Capnodis tenebrionis and C. carbonaria adults emergence accelerated with temperatures higher than $30^{\circ} \mathrm{C}\left(29^{\text {th }}\right.$ June) and peaked on $24^{\text {th }}$ August when temperature was recorded as $37^{\circ} \mathrm{C}$ in 2010 (Karaca, 2012). In addition, Karaca (2012) reported that $C$. tenebrionis and $C$. carbonaria adults' emergence accelerated with temperatures higher than $30^{\circ} \mathrm{C}\left(29^{\text {th }}\right.$ June) and peaked on $24^{\text {th }}$ August when temperature was recorded as $37^{\circ} \mathrm{C}$ in 2011 . On the dates on which high numbers of catches of $C$. tenebrionis were observed with the maximum temperatures of 37,31 , 30.9 and $30.4^{\circ} \mathrm{C}$ on $10^{\text {th }}$ July, $14^{\text {th }}$ August, $28^{\text {th }}$ August and $4^{\text {th }}$ September respectively. The maximum temperature was $40.2^{\circ} \mathrm{C}$ on $31^{\text {st }}$ July when the highest number of $C$. carbonaria catches was observed (Karaca, 2012).

Feeding and flight activity increase in higher temperatures (Isard et al., 1999; Bonsignore and Bellamy, 2007). Feeding activity was most marked between $25^{\circ} \mathrm{C}$ and $40^{\circ} \mathrm{C}$. No feeding was observed at temperatures below $20^{\circ} \mathrm{C}$ (Bonsignore and Bellamy, 2007). The optimal temperature for feeding, movement and flight was $30^{\circ} \mathrm{C}$ and above with negative effects occurring at $45^{\circ} \mathrm{C}$ (Bonsignore and Bellamy, 2007). The highest levels of activity occurred at high mean temperatures of between $30^{\circ} \mathrm{C}$ and $40^{\circ} \mathrm{C}$, and the beetles were less active at low temperatures; at $15^{\circ} \mathrm{C}$ movement is already limited. Flight generally occurred in the middle of the day (Bonsignore and Bellamy, 2007).

The damage rates of $C$. tenebrionis and C.carbonaria were different in each of the apricot orchards and sampling year. The damage levels observed and the details of the orchards on 2010 are given as follows; $30 \%$ 'Kabaaşı + Hacıhaliloğlu' (3 years old), 22.2\% 'Kabaaşı' (7 years old), 14.8\% 'Hacıhaliloğlu + Hasanbey' (more than 25 years old), 6.6\% 'Hacıhaliloğlu + Hasanbey' (10-15 years old), 3.7\% 'Kabaaşı' (more than 20 years old), $2 \%$ 'Hacıhaliloğlu + Hasanbey' (more than 20 years old), $0.7 \%$ 'Hacıhaliloğlu + Kabaaşı + Hasanbey +Çataloğlu' (more than 20 years old) (Table 2).

The damage levels observed and the details of the orchards on 2011 as follows; 30\% 'Kabaaşı + Hacıhaliloğlu' (4 years old), 16.6\% 'Hacıhaliloğlu + Hasanbey' (more than 25 years old), 10.2\% 'Kabaaşı' (more than 20 years old), 8.3\% 'Hacıhaliloğlu + Hasanbey' (10-15 years old), 2\% 'Hacıhaliloğlu + Hasanbey' (more than 20 years old), 1.3\% 'Hacıhaliloğlu + Kabaaşı + Hasanbey + Çataloğlu' (more than 20 years old).

Table 2. Districts and village of sampled apricot orchards, their varieties, age, number of trees and and damage rates (\%) in 2010-2011.

\begin{tabular}{|c|c|c|c|c|c|c|}
\hline \multirow[t]{2}{*}{ Districts/village } & \multirow{2}{*}{$\begin{array}{l}\text { Sampled } \\
\text { orchards }\end{array}$} & \multirow[t]{2}{*}{ Varieties of apricot } & \multirow[t]{2}{*}{ Age } & \multirow{2}{*}{$\begin{array}{c}\text { Number of } \\
\text { trees }\end{array}$} & \multicolumn{2}{|c|}{ Damage rates (\%) } \\
\hline & & & & & 2010 & 2010 \\
\hline Akçadağ/ Bahri & Orchard I & Kabaaşı & 3 & 40 & 30 & 30 \\
\hline Akçadağ/ Bahri & Orchard II & Kabaaşı+Hacıhaliloğlu & 20 & 107 & 3,7 & 10,2 \\
\hline Battalgazi/Merkez & Orchard I & Hacıhaliloğlu+Hasanbey & $20 \geq$ & 98 & 2,0 & 2,0 \\
\hline Battalgazi/ Merkez & Orchard II & Hacıhaliloğlu+Hasanbey & $25 \geq$ & 54 & 14,8 & 16,6 \\
\hline Battalgazi/Merkez & Orchard III & Hacıhaliloğlu+Hasanbey & $10-15$ & 60 & 6,6 & 8,3 \\
\hline Doğanşehir/Sürgü & Orchard I & Kabaaşı & 7 & 45 & 22,2 & - \\
\hline $\begin{array}{l}\text { Doğanşehir/Cumhuriyet } \\
\text { Örnek Köy }\end{array}$ & Orchard II & $\begin{array}{l}\text { Hacıhaliloğlu + Kabaaşı + } \\
\text { Hasanbey+Çataloğlu }\end{array}$ & $20 \geq$ & 1000 & 0,7 & 1,3 \\
\hline
\end{tabular}

Mendel et al. (2003) reported that the mean "host preference"for $C$. tenebrionis (beetle per tree per counting) for $C$. tenebrionis as arranged from the highest to the lowest value per tree was as follows: plum $>$ apricot $>$ peach $>$ almond $>$ apple. Moreover, Mendel et al. (2003) reported that the pattern of host preference by $C$. carbonaria was different from that of its congener: peach > almond >plum > apricot $>$ apple. Occurrence on peach was significantly higher than on the two latter scions. The mean number of eggs of $C$. carbonaria per scion as arranged from the highest to the lowest values per "tree" was peach > plum > apricot >almond > apple. Tezcan et al. (2011) reported that the percentage of $C$. tenebrionis infested saplings and the number of larvae per sapling arranged from the highest to the lowest for cultivar as follows: Şekerpare > Soğancı > X1 Zerdali > Kabaaşı > Tokaloğlu > Adilcevaz 2 $>$ X2 Zerdali > Şam > Adilcevaz $1>$ Hacıhaliloğlu > Adilcevaz $4>$ Hasanbey, whereas the percentage of $C$. carbonaria infested saplings and the number of larvae per sapling arranged from the highest to the lowest for cultivars as follows: Adilcevaz $1>$ Adilcevaz $2>\mathrm{X} 2$ 
Zerdali > X1 Zerdali > Hacıhaliloğlu > Soğancı > Hasanbey $>$ Şam $>$ Adilcevaz 4 .

In conclusion, the present study was conducted to determine seasonal population fluctuations and damages rates of $C$. tenebrionis $\mathrm{L}$. and $C$. carbonaria $\mathrm{L}$. (Coleoptera: Buprestidae) in apricot orchards in Malatya province. After two years of the study, the seasonal population fluctuations of the pests varied between each sampling year. A total of 1020 Capnodis adults were collected in 2010 from all the sampling areas. Among these, 805 were $C$. tenebrionis (6880 $: 117 \%$ ) and 215 were C. carbonaria (1930':22\%). A total of 1170 Capnodis adults were collected in 2011 from all the sampling areas. Among these, 903 were $C$. tenebrionis (7900':113\%) and 267 were C. carbonaria $\left(2250^{n}: 42 \%\right)$. The total number of $C$. tenebrionis was higher than $C$. carbonaria in both years. In addition, the total number of male was higher than female in both years. In 2010, the highest number of $C$. tenebrionis male were collected in August, July and September, while female collected in August, September and July. The highest number of $C$. carbonaria male and female were collectd in August, September and July. In 2011, the highest number of $C$. tenebrionis male and female were collected in July, August, September and June. The highest number of $C$. carbonaria male were collected in July, August, September and June, while the female collected in July, August and June. The damage rates were observed on various varieties between 0.7$30 \%$ in 2010 and $1.3-30 \%$ in 2011.

\section{ÖZET}

Amaç: Malatya ili kayısı bahçelerinde Capnodis tenebrionis L. ve Capnodis carbonaria L. (Coleoptera: Buprestidae) türlerinin mevsimsel popülasyon yoğunlukları ile zarar oranlarının belirlenmesidir.

Yöntem ve Bulgular: Çalışma 2010-2011 yıllarında Malatya illinin Akçadağ, Battalgazi ve Doğanşehir ilçelerinde bulunan on üç kayısı bahçesinde yürütülmüştür. Çalışma 2010 yılında yedi, 2011 yılında altı kayısı bahçesinde gerçekleştirilmiştir. Her iki yılda da örneklenen kayısı bahçeleri her hafta ziyaret edilmiş ve görsel inceleme yöntemiyle Capnodis erginleri toplanmıştır. Çalışmanın sonucunda zararlıları popülasyon yoğunlukları örnekleme yapılan yıllara göre farklılık göstermiştir. 2010 yılında bütün örnekleme alanlarından toplam 1020 adet Capnodis ergini toplanmıştır. Toplanan erginlerin 805 adedi $C$. tenebrionis (6880:117\%), 215 adedi de C. carbonaria (1930': 229)'dır. İlk C. tenebrionis erkek ergin çıkış 27
Nisan'da olurken, ilk dişi ergin çıkışı 18 Mayıs'da gözlenmiştir. Örnekleme süresince en fazla erkek ve dişi birey 24 Ağustos tarihinde yakalanmıştır. Ilk $C$. carbonaria erkek ergin çıkışı 22 Haziran'da olurken, ilk dişi ergin çıkışı 20 Temmuz'da gözlenmiştir. 2011 yılında bütün örnekleme alanlarından toplam 1170 adet Capnodis ergini toplanmıştır. Toplanan erginlerin 903 adedi $C$. tenebrionis (7900":113\%), 267 adedi de $C$. carbonaria (2250':42\%)'dır. Illk C. tenebrionis erkek ergin çıkışı 23 Nisan'da olurken, ilk dişi ergin çıkışı 30 Nisan'da gözlenmiştir. Örnekleme süresince en fazla erkek birey 21 Ağustos ve dişi bireylere ise 28 Ağustos tarihinde rastlanmıştır.

Genel Yorum: 2010 yılında, C. tenebrionis'in erkekleri en yüksek rastlanma yüzdesi ağustos, temmuz ve eylül aylarında, dişiler ise ağustos, eylül ve temmuz aylarında toplanmıştır. C. carbonaria'nın erkek ve dişileri en yüksek rastlanma yüzdesi ağustos, eylül ve temmuz aylarında toplanmıştır. 2011 yılında, C. tenebrionis'in erkek ve dişileri en yüksek rastlanma yüzdesi temmuz, ağustos, eylül ve haziran aylarında elde edilmiştir. $C$. carbonaria erkekleri en yüksek rastlanma yüzdesi temmuz, ağustos, eylül ve haziran aylarında, dişiler ise temmuz, ağustos ve haziran aylarında toplanmıştır.

Çalışmanın Önemi ve Etkisi: Çalışmada daha fazla sayıda $C$. tenebrionis ergini görsel inceleme yöntemiyle toplanmıştır. Her iki yılda da C. carbonaria'dan daha fazla sayıda $C$. tenebrionis ergini toplanmıştır. Örnekleme yapılan çeşitlerde 2010 yılında \% 0,7-30 ve 2011 yılında \% 1,3-30 arasında zarar oranları belirlenmiştir.

Anahtar Kelimeler: Capnodis tenebrionis, Capnodis carbonaria, kayısı, populasyon yoğunluğu, zarar oranı, Malatya.

\section{ACKNOWLEDGEMENTS}

This project was supported by University of Hatay Mustafa Kemal of Scientific Research Projects (BAP) (project number: 1101 Y 0104).

\section{CONFLICT OF INTEREST}

The authors declared no potential conflicts of interest with respect to the research, authorship, and/or publication of this article.

\section{AUTHOR'S CONTRIBUTIONS}

The contribution of the authors is equal. 


\section{REFERENCES}

Ak K, Çam H (1998) Tokat ilinde bulunan Buprestidae (Coleoptera) türleri üzerinde faunistik çalışmalar. Gaziosmanpaşa Üniversitesi, Ziraat Fakültesi Dergisi 15(1): 31-45.

Asma BM (2000) Apricot production (in Turkish). Evin Press, Malatya.

Asma BM, Birhanlı, O (2004) Mişmiş (in Turkish). Evin Press, Malatya.

Ben Yehuda S, Assaele F, Mendel Z (2000) Improved chemical control of Capnodis tenebrionis and $C$. carbonaria in stone-fruit plantations in Israel. Phytoparasitica 28: 1-16.

Beu-Yebuda S, Assael E, Mendel Z (1997) Recent outbreaks of phloem- and wood-boring insects in deciduous orchards in Israel. Phytoparasitica 25: 163-164.

Bonsignore CP, Bellamy C (2007). Daily activity and flight behaviour of adults of Capnodis tenebrionis (L.) (Coleoptera: Buprestidae). European Journal of Entomology 104: 425-431.

Bonsignore CP, Manti F, Vacante V (2007). Field and tree distribution of Capnodis tenebrionis (L.) (Linnaeus, 1767) (Coleoptera, Buprestidae) adults in an apricot orchard in Italy. Journal of Applied Entomology 132: 216-224.

Çınar M, Çimen I, Bolu H (2004) Elazığ ve Mardin Illeri kiraz ağaçlarında zararlı olan türler, doğal düşmanları ve önemlileri üzerinde gözlemler. Türkiye Entomoloji Dergisi 28(3): 213-220.

Dicenta F, Cánovas JA, Soler A, Berenguer V (2011) Relationship between almond bitterness and resistance to capnode. ITEA Producción Vegetal. 97(3): 289-294.

Ercişli S (2009) Apricot culture in Turkey. Scientific Research and Essay 4(8): 715-719.

Ertop S, Özpınar A (2011) Çanakkale ili kiraz ağaçlarındaki fitofag ve yararlı türler ile bazı önemli zararlıların popülasyon değişimi. Türkiye Entomoloji Bülteni 1(2): 109-118.

FAO (2018) Production Quantities of Apricots by Country in 2017; Crops/World Regions / Production Quantity from picklists". Food and Agriculture Organization of the United Nations, Statistics Division (FAOSTAT). 2018. Retrieved 2019-02-19.

Garcia-del-pino F, Morton A (2005) Efficacy of entomopathogenic nematodes against neonate larvae of Capnodis tenebrionis (L.) (Coleoptera: Buprestidae) in laboratory trials. BioControl 50: 307316.
Gindin G, Kuznetsova T, Protasov A, Ben Yehuda S, Mendel Z (2009) Artificial diet for two Flat-Headed Borers, Capnodis spp. (Coleoptera: Buprestidae). European Journal of Entomology 106: 573-581.

Isard SA, Nasser NA, Spencer JL, Levine E (1999) The influence of the weather on western corn rootworm flight activity at the borders of a soybean field in east central Illinois. Aerobiologia 15: 95-104.

Kanat M, Tozlu G (2001) Kahramanmaraş ilinde bulunan Buprestidae (Coleoptera) familyasi türleri üzerinde faunistik bir araştırma. Atatürk Üniversitesi Ziraat Fakültesi Dergisi 32(3): 223-231.

Karaca Z (2012) Malatya ili kayısı bahçelerinde bulunan Capnodis türleri, yoğunlukları ve zarar oranlarının belirlenmesi. Mustafa Kemal Üniversitesi, Fen Bilimleri Enstitüsü, pp: 78.

Karaca Z, Demirel N (2011) Malatya ili kaysı bahçelerinde bulunan Capnodis spp. (Coleoptera: Buprestidae) türleri yaygınlıkları ve yoğunluklarının belirlenmesi. Türkiye IV. Bitki Koruma Kongresi Bildirileri 28-30 Haziran 2011, Kahramanmaraş, 205.

Lodos N, Tezcan S (1995) Türkiye Entomolojisi V Buprestidae (Genel uygulamalı ve faunistik). Entomoloji Derneği Yayınları, No: 8: Ege Üniversitesi Basımevi, Bornova/ İzmir, pp: 138.

Malagon J (1989) Bioecolog/a de Capnodis tenebrionis L. (Col. Buprestidae) e influencia de ciertos factores abi6ticos sobre sus estados inmaduros, en el momento de la eclosi6n del huevo y su penetraci6n en huespedes de interes agricola. Ph.D. thesis, Polytechnic University of Valencia, Spain.

Martin P, Soria FJ, Villagran M, Ocete ME (1998) Food preference of the adult of Capnodis tenebrionis L. (Coleoptera: Buprestidae) for six plant species in the laboratory. Bol. Sanid. Veget. Plagas 24: 107-112.

Mendel Z, Assael F, Ben-Yehuda S (2003) Host selection and root colonization of cyanogenic stonefruit species by Capnodis spp. (Coleoptera: Buprestidae). Ann. Entomol. Soc. Am. 96(2): 127-134.

Rivnay E (1944) Physiological and ecological studies on the species of Capnodis, in Palestine (Col., Buprestidae): 1. Studies on the eggs. Bull. Entomol. Res. 35:235-242.

Rivnay E (1945) Physiological and ecological studies on the species of Capnodis, in Palestine (Col., Buprestidae): II. Studies on the larvae. Bull. Entomol. Res. 36: 103-119.

Rivnay E (1946) Ecological and physiological studies on Capnodis spp. (Col., Buprestidae) in Palestine: 111. Studies on the adult. Bull. Entomol. Res., 37:273280. 
SAS Institute. (1990) User's Guide, version 6. SAS Institute, Cary, NC, USA.

Tezcan S (1990) İzmir ilinde bulunan Sphenopterini, Buprestini ve Psilopterini (Coleoptera: Buprestidae: Buprestinae) tribus'larına bağlı türler üzerinde sistematik araştırmalar. E.Ü.Fen Bil.Enst.Bit.Koruma Anabilim Dalı, Doktora Tezi. 162 s. Bornova-izmir.

Tezcan S (1995) Kemalpaşa (Izmir) yöresi kiraz ağaçlarında zararlı Buprestidae (Coleoptera) familyası türleri üzerinde araştırmalar. Türkiye Entomoloji Dergisi 19(3): 221-230.

Tezcan S, Evrenosoğlu Y, Mısırlı A, Gülcan R, Gülperçin N (2011) Prunasin contents of Turkish apricot cultivars and artificial infestation of rootstocks by Capnodis tenebrionis (Linnaeus, 1758) and Capnodis carbonaria (Klug, 1829) (Coleoptera: Buprestidae). Türk. Entomol. Derg. 35(3): 407-421.
Tozlu G, Özbek H (2000) Erzurum, Erzincan, Artvin ve Kars illeri Buprestidae (Coleoptera) familyası türleri üzerinde faunistik ve taksonomik çalışmalar II. Sphenopterinae, Chalcophorinae, Chrysobothrinae, Agrilinae, Cylindromorphinae ve Trachyinae. Turk Journal of Zoology 24: 79-103.

Vit K (2004) Fauna Europaea: Buprestidae. In: AlonsoZarazaga M.A. (ed.), Fauna Europaea: Coleoptera. Fauna Europaea version 1.1. http://www.faunaeur.org

Zobar D, Kıvan M (2019) Tekirdağ ilinde farklı anaçlı kiraz bahçelerinde Capnodis tenebrionis (L.) (Coleoptera: Buprestidae)'in mevsimsel gelişimi. Tekirdağ Ziraat Fakültesi Dergisi 16(3): 339-347.

Zobar D, Kıvan M, Candar S, Yaşasın A (2019) Buprestidae (Coleoptera) species in stone fruit trees in Tekirdağ province. Plant Protection Bulletin 59-4. 